Acta vet. scand. $1968,9,50-64$.

From the State Veterinary Serum Laboratory, Copenhagen and the State Veterinary Institute for Virus Research, Lindholm, near Kalvehave, Denmark.

\title{
STUDY OF THE PRACTICABILITY OF VARIOUS DIAGNOSTIC METHODS IN THE DEMONSTRATION OF SWINE FEVER VIRUS OF HIGH AND LOW VIRULENCE IN ORGANS OF EXPERIMENTALLY INFECTED PIGS*)
}

By

A. Meyling and K. Schjerning-Thiesen

European swine fever has not been diagnosed in Denmark since 1933. However, it is still rife in many other countries, including Germany and the Netherlands, and thus it is natural that also in Denmark efforts should be made to find a rapid and safe diagnostic procedure for this disease.

Inoculation experiments with suspect tissue material on immunized and susceptible pigs is the method commonly used in the demonstration of swine fever. However, weakly virulent virus strains are often difficult to diagnose by that means, since such strains often cause mild disease even in very sensitive animals. Repeated inoculation at a later stage with virus known to be strongly virulent is therefore necessary in order to see if immunity has been provoked by inoculation of the suspect material. This method is therefore very time-consuming.

During recent years great efforts have been made to develop effective laboratory methods for routine diagnosis of swine fever. Among these methods staining with fluorescent antibodies (FA), the complement fixation test (CFT) and the agar gel diffusion (AGT) are the most important. FA staining is used for

*) Aided by a grant from Statens almindelige Videnskabsfond. 
demonstration of virus either in tissue sections from infected animals or in inoculated tissue cultures. Complement fixation and agar gel diffusion are based on the presence of virus in the spleen and pancreas of diseased animals. These two methods do not require as much technical equipment as FA staining, but are less sensitive.

The primary aim of the present study was to investigate the practicability of the above-mentioned laboratory methods for the demonstration of such virus strains as would most likely be involved in a possible outbreak of swine fever in Denmark. The experiments have therefore been carried out on Danish Landrace pigs inoculated with a strongly virulent and a weakly virulent virus strain of German origin.

\section{MATERIAL AND METHODS}

Inoculation of pigs. Two inoculation experiments were carried out on 20 Danish Landrace pigs.

In Experiment I five pigs weighing about $40 \mathrm{~kg}$, and five weighing from 20 to $30 \mathrm{~kg}$, were inoculated intravenously in the ear, each with $5 \mathrm{ml}$ blood with sodium citrate added. The blood originated from diseased pigs infected artificially with strongly virulent virus.

In Experiment II ten pigs weighing from 25 to $30 \mathrm{~kg}$ were inoculated intravenously in the ear with weakly virulent virus, each animal receiving $2 \mathrm{ml}$ of a $10 \%$ spleen extract in $0.02 \mathrm{M}$ phosphate buffer, $\mathrm{pH}$ 7.6. Prior to the inoculation the presence of virus in the spleen used for production of the extract had been ascertained by the FA tissue-culture method.

Whenever animals were sacrificed for supply of infected organ material, those were selected which clinically appeared to be most severely affected.

Autopsy material for FA staining was placed in plastic bags and kept under refrigeration. At least $24 \mathrm{hrs}$. would elapse before the material could be further processed for FA examination. Spleen and pancreas tissues for CFT and AGT were stored at $-60^{\circ} \mathrm{C}$ until these tests could be made.

Virus. Two German strains of different virulence were used. The one, a strongly virulent strain isolated from an outbreak at Minden, near Hannover, was used in Experiment I after two previous passages on pigs. The other, a weakly virulent strain originating from a herd at Spielbach, Nord-Württemberg, was used in Experiment II without previous passages*).

Production of immune serum. Pigs weighing from 25 to $30 \mathrm{~kg}$ were used for this purpose. They were vaccinated with crystal violet

*) Dr. Georg Korn, Tübingen, has demonstrated that this virus is weakly virulent and immunogenic. 
vaccine and challenged one month later with $1 \mathrm{ml}$ virulent blood. A blood sample taken ten days after challenge was examined by means of the agar gel diffusion test (Darbyshire $1962 \mathrm{~b}$ ).

\section{Fluorescent Antibodies (FA)}

Demonstration of swine fever virus by FA was carried out partly by direct staining of cryostat sections, partly by staining of tissue cultures inoculated with tissue suspensions from spleen, lymph nodes and tonsils.

Production of conjugates. Several conjugates of varying quality were prepared from serum from pigs immunized as mentioned above, as well as from commercial serum ${ }^{*}$ ). The globulins were precipitated by $40 \%$ saturation with ammonium sulphate. After 20 hrs. the precipitate was removed by centrifugation and thereafter dissolved in destilled water. The remaining ammonium ions were eliminated by gel filtration on Sephadex G-25**). The protein concentration of the solution, determined by the biuret method, was adjusted to $1 \%$ with bicarbonate-carbonate buffer $(0.25 \mathrm{M}, \mathrm{pH} 9.0)$, and conjugation carried out as described by Cherry et al. (1961), using $0.025 \mathrm{mg}$ fluorescein isothiocyanate (FITC) ${ }^{* * *}$ ) per $\mathrm{mg}$ protein. Free fluorescein was removed by gel filtration on Sephadex G-25. Before use, the conjugate was treated with freeze-dried pig kidney powder in order to absorb non-specific staining components.

Preparation of cryostat sections. Blocks of tissue were cut into suitable sizes and frozen to the metal holders of the cryostat by means of dry ice. Sections of a thickness of $6 \mu$ were prepared, dried at room temperature, and fixed in acetone for $10 \mathrm{~min}$.

Tissue culture technique. Primary cell cultures prepared from the kidneys of about 6-month-old slaughter pigs were employed. The tissue cultures were prepared in Leighton tubes with $9 \times 35 \mathrm{~mm}$ cover slips. The medium was Earle's saline solution with $0.5 \%$ lactalbumin and $10 \%$ calf serum, and with 100 i.u. penicillin and $0.1 \mathrm{mg}$ streptomycin per ml. The same medium, though with only $2 \%$ calf serum and the double amount of antibiotics, was used for maintenance.

Tissues for inoculation of cultures were prepared as follows:

Pieces of tissue were ground in a mortar with maintenance medium $(1+4)$. After centrifugation $30 \mathrm{~min}$. at 4000 r.p.m. $0.1 \mathrm{ml}$ of the supernatant was inoculated into each culture.

As no positive results were obtained in Experiment II additional inoculation was carried out with $1 \mathrm{ml}$ of undiluted supernatant per culture. After $1 \mathrm{hr}$. at room temperature to allow for absorption, the cultures were incubated with new medium. Four tubes were inoculated from each specimen so that for the following 4 days cover slips could be taken out daily for staining and examination.

*) Beringwerke A.G., Marburg/Lahn, Germany.

**) Pharmacia, Uppsala, Sweden.

${ }^{\star * *}$ ) Baltimore Biological Laboratories Inc., Baltimore, Maryland, U.S.A. 
Tissue cultures were incubated at $37^{\circ} \mathrm{C}$.

Staining and microscopy. Staining and mounting of sections were carried out as described previously (Meyling \& Bitsch 1967).

One set of sections was stained with conjugate diluted 1:4 in normal pig serum, another identical set with conjugate diluted 1:4 in non-conjugated SF-immune serum. A marked decrease in the intensity of fluorescence in the latter preparations proved the specificity of the staining. As a further control staining was made also of sections of organs from healthy pigs.

When used for staining tissue cultures the conjugate was diluted with PBS.

Microscopy was carried out with a Reichert Zetopan microscope fitted with HB200 mercury and incandescent lamps, as well as with the necessary filters.

\section{Complement Fixation Test (CFT)}

The direct modified CFT as described by Boulanger (1960) and Boulanger et al. (1965) was used, with spleen tissue as antigen. It was necessary to take into account during performance of the test that immune sera showed a procomplementary effect and that the spleen extracts used as antigens were often more or less anticomplementary.

Pilot studies with various extraction methods had shown that the best results were obtained when the antigen was prepared by the method described by Zakin (1964), using chloroform for purification. This method was therefore used throughout this study. Negative control antigen was prepared in the same manner from spleens selected at random from healthy slaughter animals.

Immune sera were produced as described above. Normal control sera were prepared from the same pigs that were later on used for production of immune sera. Sera were stored in amounts of $2 \mathrm{ml}$ at $-20^{\circ} \mathrm{C}$ and heat-inactivated at $56^{\circ} \mathrm{C}$ for $30 \mathrm{~min}$. before use.

All dilutions and suspensions used in the test were made in veronal-buffered saline containing $\mathrm{Ca}$ and $\mathrm{Mg}$ ions.

Complement was diluted in veronal buffer to which serum $(19+1)$ from 4- to 6-month-old calves had been added just before use (Boulanger et al.). New calf sera were always tested against an old, but still usable calf serum. Usable sera, which were rather few, were stored in small portions at $-20^{\circ} \mathrm{C}$ and were considered usable for $1 \frac{1 / 2}{2}$ months only.

The haemolytic system was prepared as described by SchjerningThiesen (1964).

Antigen, serum and complement were used in $0.1 \mathrm{ml}$ doses, the haemolytic system in a dose of $0.2 \mathrm{ml}$, thus making a total volume of $0.5 \mathrm{ml}$. Incubation was carried out for $18 \mathrm{hrs}$. at $0^{\circ} \mathrm{C}$ and after addition of the haemolytic system for $1 \mathrm{hr}$. at $32^{\circ} \mathrm{C}$.

After production, immune and normal sera (known components) were tested for influence on the activity of complement and for specific complement-fixing potency. 
The influence on complement activity was determined by titrating, on the one hand, complement alone and, on the other hand, complement mixed with a constant amount of serum $(0.1 \mathrm{ml}$ of dilution $1: 2)$. Serum was always found to be more or less procomplementary, i.e., $50 \%$ haemolysis was achieved with less complement when serum was present.

The specific complement-fixing potency was determined by adding, respectively, known negative and known positive antigen $(0.1 \mathrm{ml})$ to two identical rows of serum dilutions $(1: 2,1: 4$, etc.) and to both rows, complement $(0.1 \mathrm{ml})$ in the dilution which in a previous titration was found to give exactly $50 \%$ haemolysis in the presence of the antigen in question. The procomplementary effect of serum manifested itself by a 50 to $100 \%$ haemolysis in the first tube in both rows. The specific complement-fixing potency was defined as the highest dilution of serum which gave haemolysis in the presence of positive antigen.

The actual examination of spleen extract from infected pigs (unknown antigens) was performed by determining the effect of the unknown antigens complement alone and thereafter their specific complement-fixing effect.

The effect against complement alone was determined by parallel titration of complement alone and complement with a constant amount of antigen $(0.1 \mathrm{ml})$. Generally the antigens were anticomplementary, i. e., a larger amount of complement was necessary to give $50 \%$ haemolysis in the presence of antigen. The amount of complement necessary to obtain $50 \%$ haemolysis in the presence of antigen alone was used in the final investigation of the specific effect of the unknown antigen (see below). The reason for using the smallest possible amount of complement, here as well as in titration of serum (see above), was the fact that many antigens had proved to have only a weak specific potency of fixation.

The specific complement-fixing effect of unknown antigen was determined by adding, respectively, negative antigen, known positive antigen, and the unknown antigen to three identical rows of known immune serum dilutions $(1: 2,1: 4$, etc.), and to all rows, complement in the dilution which in a previous titration had caused exactly $50 \%$ haemolysis in the presence of the antigen in question. The three antigens were tested in the same way as with normal serum and, in addition, in a blind test without serum in order to make sure that the complement was measured out correctly.

In view of the procomplementary effect of the sera, antigens were tested against several serum dilutions in order to ensure an optimal amount of antibody.

\section{Agar Gel Diffusion Test}

This test was performed as described by Darbyshire (1962 a). 


\section{RESULTS}

In Experiment I, in which strongly virulent virus was used all inoculated pigs showed a typical reaction, i.e., high temperature and lassitude on the third to fifth day after inoculation. Subsequently there was a decrease in temperature, but all the pigs still had fever on the day they were killed. Furthermore, eight of the ten pigs showed nervous symptoms in the form of ataxia, or ataxia and convulsions at some time or other before being killed.

In Experiment II, in which the weakly virulent strain was used, the clinical reactions of the pigs were much less pronounced than in Experiment I. The animals could therefore be killed at longer intervals and diagnostic tests carried out on organs of animals with a more chronic course of disease. The individual resistance of the experimental animals was particularly apparent after infection with this strain. One of the animals (no. 22) died 21 days after infection, while two (nos. 16 and 35) recovered completely after a few days with fever.

$F A$ staining of sections. In all cases the intracellular distribution of fluorescence, as seen in cryostat sections of the various organs, corresponded to the picture known from tissue cultures infected with SF virus (Mengeling et al. 1963, Robertson et al. 1965a). With both types of virus the specific intracellular fluorescence was diffuse and cytoplasmic, with the highest intensity around the nucleus.

With a specific staining of this character, it is of particular importance to work with conjugates that are absolutely free from nonspecific staining components. A single treatment of the conjugates with freeze-dried pig kidney powder proved to be sufficient in this respect. Specific fluorescence with acceptable intensity and good contrast could be achieved when microscopy was carried out with monocular tube, pure ultraviolet light, and colourless secondary filter. Noninfected cells were greyish-blue, while infected cells showed a clear green fluorescence in the cytoplasm and no staining of the nucleus.

It will be seen from Table 1 that in Experiment $I$ it was possible to demonstrate virus directly in almost all the organs examined. Only one of the spleens was negative (two tissue blocks were lost in the course of processing). The number of infected cells varied considerably, however. As observed also by 
T a b l e 1. Summary of clinical and post mortem findings and results of examinations by FA, CFT and AGT of 20 pigs experimentally infected with SF virus.

\begin{tabular}{|c|c|c|c|c|c|c|c|c|c|c|c|c|c|c|c|}
\hline & & \multirow[b]{2}{*}{$\begin{array}{l}\dot{a} \\
\dot{0} \\
\dot{0}\end{array}$} & \multirow{2}{*}{ 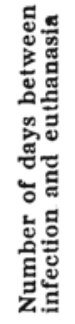 } & \multirow{2}{*}{ 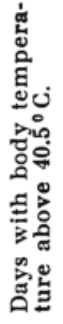 } & \multirow{2}{*}{ 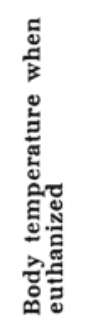 } & \multirow[b]{2}{*}{ 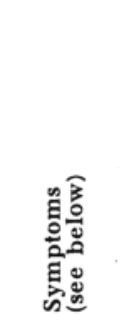 } & \multirow{2}{*}{ 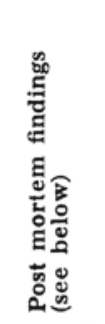 } & \multicolumn{6}{|c|}{$\mathrm{FA}$} & \multirow{2}{*}{$\begin{array}{l}\text { CFT } \\
\\
\text { ळँّ }\end{array}$} & \multirow{2}{*}{ 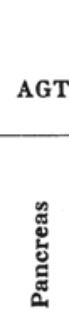 } \\
\hline & & & & & & & & $\begin{array}{l}\dot{\dot{s}} \\
\dot{\dot{c}}\end{array}$ & ن & $\begin{array}{l}\dot{\dot{S}} \\
\dot{\dot{\theta}}\end{array}$ & ن & $\underset{\mathbf{n}}{\mathrm{Ly}}$ & $\mathrm{e}$ & & \\
\hline 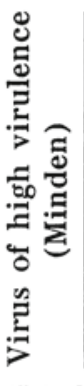 & I & $\begin{array}{r}2 \\
8 \\
4 \\
10 \\
1 \\
6 \\
3 \\
7 \\
5 \\
9\end{array}$ & $\begin{array}{r}4 \\
4 \\
6 \\
6 \\
8 \\
8 \\
11 \\
11 \\
14 \\
14\end{array}$ & $\begin{array}{r}1 \\
2 \\
2 \\
3 \\
5 \\
4 \\
6 \\
5 \\
11 \\
10\end{array}$ & $\begin{array}{l}41.0 \\
41.8 \\
41.0 \\
41.0 \\
41.5 \\
41.7 \\
40.4 \\
41.6 \\
40.5 \\
41,2\end{array}$ & $\begin{array}{l}1 \\
1 \\
1,2,3 \\
1,2,3 \\
1,2 \\
1,2 \\
1,2,3 \\
1,2,3 \\
1,2 \\
1,2,3,4\end{array}$ & 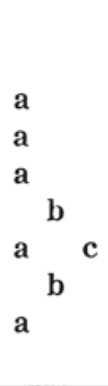 & $\begin{array}{l}+ \\
0 \\
+ \\
+ \\
\text { NE } \\
\text { NE } \\
+ \\
+ \\
+ \\
+\end{array}$ & $\begin{array}{l}+ \\
+ \\
+ \\
+ \\
+ \\
+ \\
+ \\
+ \\
+ \\
+\end{array}$ & $\begin{array}{l}+ \\
+ \\
+ \\
+ \\
+ \\
+ \\
+ \\
+ \\
+ \\
+\end{array}$ & $\begin{array}{l}+ \\
+ \\
+ \\
\phi \\
+ \\
+ \\
\phi \\
+ \\
+ \\
\phi\end{array}$ & $\begin{array}{l}+ \\
+ \\
+ \\
+ \\
+ \\
+ \\
+ \\
+ \\
+ \\
+\end{array}$ & $\begin{array}{l}+ \\
+ \\
+ \\
+ \\
+ \\
+ \\
+ \\
+ \\
+ \\
+\end{array}$ & $\begin{array}{l}0 \\
0 \\
0 \\
0 \\
+ \\
0 \\
+ \\
+ \\
+ \\
0\end{array}$ & $\begin{array}{l}0 \\
0 \\
+ \\
+ \\
+ \\
0 \\
+ \\
+ \\
0 \\
0\end{array}$ \\
\hline 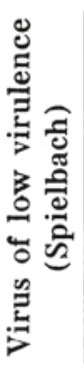 & II & $\begin{array}{l}17 \\
18 \\
15 \\
19 \\
13 \\
20 \\
14 \\
22 \\
16 \\
21\end{array}$ & $\begin{array}{r}6 \\
6 \\
10 \\
10 \\
17 \\
17 \\
21 \\
21 \bullet \\
35 \\
35\end{array}$ & $\begin{array}{r}3 \\
3 \\
4 \\
7 \\
10 \\
10 \\
8 \\
13 \\
17 \\
5 \\
3\end{array}$ & $\begin{array}{l}40.6 \\
40.7 \\
39.0 \\
41.0 \\
40.5 \\
40.7 \\
38.3 \\
41.0 \\
39.5 \\
39.5\end{array}$ & $\begin{array}{ll}1 & \\
1 & \\
1 & 3 \\
1 & \\
1 & \\
1 & \\
1 & \\
1 & \\
1 & \\
1 & \end{array}$ & $\begin{array}{ll}a & \\
a & \\
a & b \\
a & \\
a & \end{array}$ & $\begin{array}{l}0 \\
+ \\
0 \\
0 \\
+ \\
+ \\
+ \\
0 \\
0 \\
0\end{array}$ & $\begin{array}{l}0 \\
0 \\
0 \\
0 \\
0 \\
0 \\
0 \\
0 \\
0 \\
0\end{array}$ & $\begin{array}{l}+ \\
+ \\
0 \\
+ \\
+ \\
+ \\
+ \\
+ \\
0 \\
0\end{array}$ & $\begin{array}{l}0 \\
0 \\
0 \\
0 \\
0 \\
0 \\
0 \\
0 \\
0 \\
0\end{array}$ & $\begin{array}{l}0 \\
0 \\
+ \\
0 \\
+ \\
+ \\
+ \\
0 \\
0 \\
0\end{array}$ & $\begin{array}{l}0 \\
0 \\
0 \\
0 \\
0 \\
0 \\
0 \\
0 \\
0 \\
0\end{array}$ & $\begin{array}{l}0 \\
0 \\
0 \\
0 \\
0 \\
0 \\
+ \\
0 \\
0 \\
0\end{array}$ & $\begin{array}{c}0 \\
+ \\
0 \\
0 \\
0 \\
0 \\
+ \\
+ \\
0 \\
0\end{array}$ \\
\hline
\end{tabular}

Symptoms:

1: Anorexia, lassitude and constipation

2: Ataxia (crossing of the hind legs)

3: Convulsions

4: Emaciation

Post mortem findings:

a: Peripheral haemorrhage

b: Infarction (spleen)

c: Infarction (intestine)

$\bullet:$ Died
Abbreviations:

CFT: Complement fixation test AGT: Agar gel diffusion test

FA: Fluorescent antibody technique cr.s.: Cryostat sections

t.c.: Tissue culture

NE: Not examined

$\emptyset$ : Culture destroyed 
Robertson et al. (1965b), only few infected cells were seen at the beginning of the disease, while larger parts of the organs were involved when the animals had had fever for some days. In some cases all cells in the field of vision were positive. In sections from spleen and lymph nodes there was always a varying number of nonspecifically stained eosinophilic granulocytes. These cells, however, which showed a yellowish-green, granular fluorescence, could easily be distinguished from the virus-infected cells, which showed a diffuse green fluorescence. In Experiment II, virus was demonstrated in four out of ten spleens, but there were only few infected cells, regardless of the time of killing. This applied also to the lymph nodes.

There were cells with specific fluorescence in the epithelium of the crypt walls of the tonsils as early as three days after infection with the strongly virulent virus. In pigs which were killed later in the disease, the lymphoid component and the basal cells of the epithelium of the mucous membrane were also affected. The large epithelial cells in the crypts showed a particularly intense fluorescence, which greatly facilitated discovery, even if there were only few infected cells in the section. In Experiment II the positive tonsils showed a similar picture, but the virus had a lesser tendency to spread to the lymphoid component and epithelial layer of the mucous membrane. Thus, in some of the tonsils the infection was clearly limited to the crypts (Fig. 1).

$F A$ staining of tissue cultures. Virus could be isolated from all the organs tested in Experiment I. In agreement with what was found by direct examination of sections, demonstration of virus was easiest in organ material taken from animals killed at a more advanced stage of the disease. Positive cells could be found in cultures as early as $\mathbf{2 4} \mathrm{hrs}$. after inoculation with spleens from pigs 1, 6 and 7, while corresponding specimens from pigs 2, 4 and 8 were positive on the third day after inoculation.

Despite the fact that specific fluorescence was found in cryostat sections from one or more organs of the first eight pigs killed in Experiment II, it was not possible to demonstrate virus in these pigs by means of tissue cultures. Two experiments were carried out with each organ, using respectively $0.1 \mathrm{ml}$ and $1 \mathrm{ml}$ of the $20 \%$ tissue suspension as inoculum. The results were negative in both cases, however. 


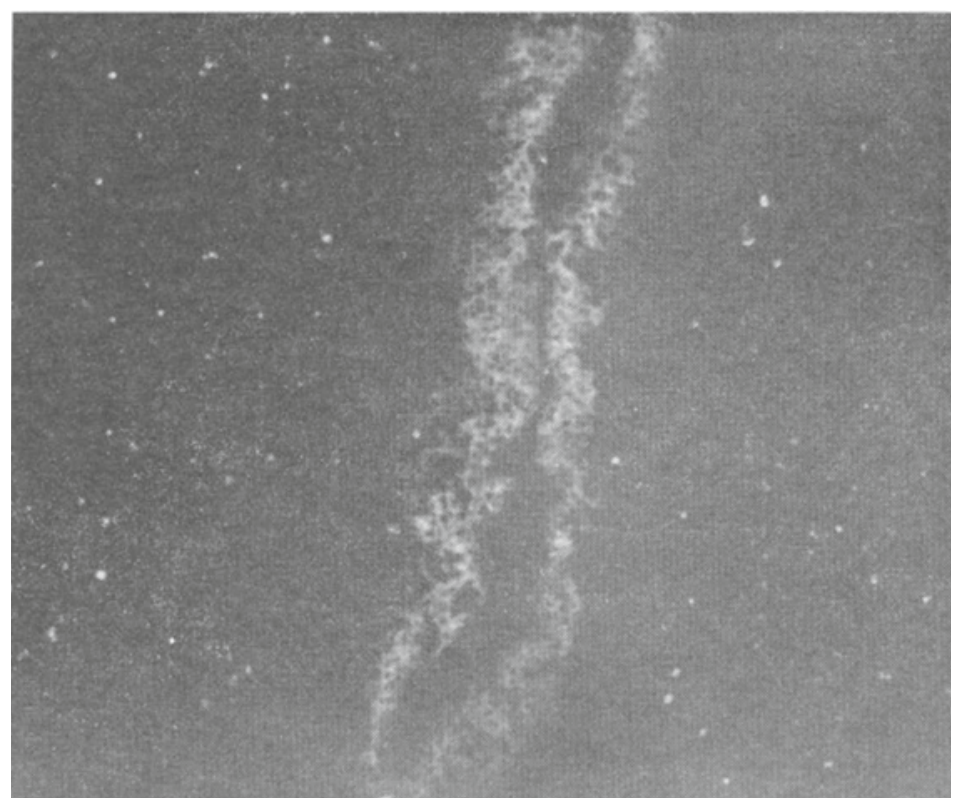

Figure 1. Cryostat section of a tonsil from pig no. 17, inoculated with weakly virulent SF virus. Fluorescent cells in the epithelial lining of a crypt.

Complement fixation test. The method used for this test is a direct technique adapted in order to ensure the greatest possible specific sensitivity. The use of minimal amounts of complement contributes essentially to this. It will be seen from the penultimate column in Table 1 that a specific complement-fixing effect was observed with spleen tissue from four pigs in Experiment I but from only a single pig in Experiment II. The positive spleens were all from pigs that had been ill for some time (in Experiment I for 8 to 14 days and in Experiment II 21 days). In four animals in Experiment I the clinical disease manifested itself as very advanced nervous symptoms.

Agar gel diffusion test. By this test, five pigs in Experiment I and three pigs in Experiment II showed a positive reaction with pancreas tissue, as shown in the last column of Table 1. The positive specimens of pancreas tissue in Experiment I were from animals with advanced swine fever. The agar gel diffusion test seems to be slightly more sensitive than the complement fixation test, since positive reactions were obtained also with organ material from animals that had been ill for 6 days only. 


\section{DISCUSSION AND CONCLUSIONS}

Clinical reactions in Danish Landrace pigs to infection with two German strains of swine fever virus varied in accordance with the virulence of the strains.

By FA staining the strongly virulent virus was easily demonstrable in cryostat sections as well as in inoculated tissue cultures. Furthermore, good results could be obtained with the agar gel diffusion and complement fixation tests when the animals were killed 6 to 14 days after inoculation.

Demonstration of the weakly virulent virus was considerably more difficult. It is true that by FA staining of cryostat sections one or more organs were found infected in eight of ten pigs, but only few infected cells could be seen in each section. The AGT was positive in three cases and the CFT in one case only. However, the most remarkable thing was the failure, even after several attempts, to demonstrate the weakly virulent virus by FA staining of tissue cultures inoculated with material from the pigs in Experiment II. This result was so much the more surprising, because at the start of the experiment it had been possible to demonstrate the virus in cultures inoculated with the original material.

The FA tissue culture method has proved its value in the control of swine fever in countries where this disease occurs (Solarzano et al. 1966). The method is reliable and rapid, and has the further advantage that it involves the isolation and identification of the infective agent. Under practical conditions, it is very important that the virus can be demonstrated rapidly also in material which is unsuitable for direct microscopical examination because of putrefaction or autolysis.

Korn \& Nishimura (1963), Korn \& Liebke (1967) and Liebke (1967) have shown that weakly virulent swine fever virus is often difficult to demonstrate in tissue cultures, be it by the HEIC method (Korn \& Nishimura, Korn \& Liebke) or by FA (Korn \& Liebke, Liebke). Numerous passages may be necessary before demonstration is possible by these methods. However, positive results can be obtained if the primary inoculum originates from animals that have reacted with typical clinical signs of swine fever (Liebke).

Carbrey (1965) suggests that the cell line $\mathrm{PK}_{15}$, generally used in the FA diagnosis of swine fever, seems to give better conditions 
for growth of SF virus than primary cultures. Liebke, however, has shown that the demonstration of weakly virulent strains of $\mathrm{SF}$ virus is very difficult, even when $\mathrm{PK}_{15}$ is used.

There is therefore good reason to believe that the unsuccessful attempts to recover the weakly virulent virus from the experimental pigs were not fortuitous.

FA staining of cryostat sections from tonsils proved to be a very effective method for the demonstration of virus. Specific fluorescence could be seen in tonsils from all ten pigs in Experiment $I$ and from seven pigs in Experiment II. This tissue was therefore the most suitable for demonstration of the weakly virulent strain.

The specific fluorescence in the tonsil crypts and the basal cell layer of the surface epithelium was more intense than that seen in the lymphoid component of the tonsils and in the spleen and lymph nodes. The high intensity seems to appear in other epithelial cells as well, particularly the renal tubular epithelium, the bronchial epithelium, and the glandular epithelium of the pancreas and salivary glands (Maess \& Liess 1966, Ressang \& Den Boer 1967, Robertson et al. 1965b, Stair et al. 1963). However, positive findings in these organs are irregular and delayed (Ressang \& Den Boer, Robertson et al. 1965b).

Teebken et al. (1967) and Aiken et al. (1967) found that the distribution of fluorescence in the tonsils is dependent on the virulence of the virus, but that by cross staining of tonsillar sections with conjugates produced with eight different SF viruses, no serological difference could be demonstrated between virulent, tissue-culture attenuated, and lapinized SF virus.

The results achieved in the present study are in agreement with these observations. The two virus strains gave the same high staining intensity, but were clearly different in their ability to invade and multiply in the cells of the organism, be it in the tonsils or in other organs.

\section{ACKNOWLEDGMENTS}

The authors wish to thank Dr. Georg Korn, Bundesforschungsanstalt für Viruskrankheiten der Tiere, Tübingen, BRD, for generously supplying sera and virus strains as well as clinical and experimental data concerning these strains. 


\section{REFERENCES}

Aiken, J. M., K. H. Hoopes, M. B. Rhodes \& M. J. Twishaus: Non-specificity of fluorescent antibody test for distinguishing hog cholera virus strains. J. Amer. vet. med. Ass. 1967, 150, 59-61.

Boulanger, P.: Technique of a modified direct complement-fixation test for viral antibodies in heat inactivated serum. Canad. J. comp. Med. 1960, 24, 262-269.

Boulanger, P., M. Appel, G. L. Bannister, G. M. Ruckerbauer, K. Mori \& D. P. Gray: Hog cholera III. Investigation of the complement fixation test for the detection of the virus in swine tissue. Canad. J. comp. Med. 1965, 29, 201-208.

Carbrey, E. A.: Routine laboratory diagnosis of hog cholera employing the fluorescent antibody tissue culture technique. FAO/OIE International Meeting on Hog Cholera and African Swine Fever. Rome 1965, May 31-June 3.

Cherry, W. B., M. Goldmann \& T. R. Carski: Fluorescent antibody techniques in the diagnosis of communicable diseases. Public Health Service Publ. no. 729. U.S. Government Printing Office, Washington D.C. 1961.

Darbyshire, J. H.: Agar gel diffusion studies with a mucosal disease of cattle I. Preliminary results with the technique. Res. vet. Sci. 1962a, 3, 118-124.

Darbyshire, J. H.: Agar gel diffusion studies with a mucosal disease of cattle II. A serological relationship between a mucosal disease and swine fever. Res. vet. Sci. 1962b, 1, 125-128.

Korn, G. \& Y. Nishimura: Zum Nachweis unterschiedlich virulenter Schweinepestvirusstämme mit der END und der HEIC-Methode. Mh. Tierheilk. 1963, 15, 328-334.

Korn, G. \& H. Liebke: Der Nachweis von schwachvirulenten Schweinepestvirus mit der HEIC-Methode und Immunofluoreszenz nach Zellkulturpassagen. Zbl. Vet.-Med. 1967, 14 (B), 49-56.

Liebke, H.: Der fluoreszenzserologischen Nachweis der Schweinepestvirus über die Gewebekultur bei experimentell infizierten Schweinen. Zbl. Vet.-Med. 1967, 14 (B), 57-67.

Maess, J. \& B. Liess: Untersuchungen mit der Immunofluoreszenzmethode zur Laboratoriumdiagnose der Europäischen Schweinepest. Zbl. Vet.-Med. 1966, 13 (B), 660-670.

Mengeling, W. L., E. C. Pirtle \& J.P. Torrey: Identification of hog cholera viral antigen by immunofluorescence, application as a diagnostic and assay method. Canad. J. comp. Med. 1963, 27, $249-252$.

Meyling, A. \& V. Bitsch: The diagnosis of pseudorabies by the fluorescent antibody technique. Acta vet. scand. 1967, 8, 360-368.

Ressang, A. A. \& J. J. Den Boer: A comparison between the cell culture, frozen tissue section, impression and mucosal smear technique 
for fluorescent antibody in the diagnosis of hog cholera. T. Diergeneesk. 1967, 92, 567-586.

Robertson, A., A. S. Greig, M. Appel, E. Girard, G. L. Bannister \& P. Boulanger: Hog cholera IV. Detection of the virus in tissue culture preparations by the fluorescent antibody technique. Canad. J. comp. Med. 1965a, 29, 234-241.

Robertson, A., G. L. Bannister, P. Boulanger, M. Appel \& D. P. Gray: Hog cholera V. Demonstration of the antigen in swine tissues by the fluorescent antibody technique. Canad. J. comp. Med. 1965 b, 29, 299-305.

Schjerning-Thiesen, K.: Studier over komplementbinding. En forbedret kvantitativ komplementbindingsteknik ved diagnosticering af aphtae epizooticae. A/S Carl Fr. Mortensen, København 1964.

Solarzano, R. F., J. E. Thigpen, D. M. Bedell \& W. L. Schwartz: The diagnosis of hog cholera by a fluorescent antibody test. J. Amer. vet. med. Ass. 1966, 149, 31-34.

Stair, E. L., M. B. Rhodes, O. D. Grace \& J. M. Aiken: Fluorescent antibody for diagnosis of hog cholera. Proc. U.S. Livestock San. A. $1963,67,599-606$.

Teebken, D. L., J. M. Aiken \& M. J. Twishaus: Differentiation of hog cholera viruses by fluorescent antibody technique. J. Amer. vet. med. Ass. 1967, 150, 53-58.

Zakin, M. M.: Aplicacion de las tecnicas de fijacion de complemento, immunofluorescencia e immuncromatografia al e studo del virus de la peste porcina. Revista de Investigaciones Agropecuarias. Buenos Aires 1964. Instituto National de Tecnologia Agropecuaria.

\section{SUMMARY}

Inoculation experiments were performed with two German strains of swine fever virus. In Experiment I, ten pigs of Danish Landrace were inoculated with a strongly virulent strain, while in Experiment II ten pigs were inoculated with weakly virulent virus.

The animals were killed at varying times after inoculation and organs taken out for examination by means of fluorescent antibodies (FA), by the complement fixation test (CFT), and by the agar gel diffusion test (AGT). Cryostat sections of tonsils, spleen and lymph nodes were examined by FA staining. Tissue suspensions from the same organs were inoculated into primary pig kidney tissue cultures, which were also stained with FA. Antigen produced from spleen tissue was used in the CFT and pieces of pancreas tissue in the AGT.

The strongly virulent virus could be demonstrated easily by FA in all the inoculated pigs, both by direct staining of cryostat sections and by staining of inoculated tissue cultures. The CFT and AGT were positive when the tested organs originated from animals killed at a more advanced stage of the disease. 
While the weakly virulent virus could be demonstrated by FA staining of tissues from eight of the ten pigs in Experiment II, virus was found in none of these animals by the FA tissue culture method. The CFT was positive in one case and the AGT in three cases.

In both experiments it was found that FA staining of cryostat sections of tonsils was a particularly suitable method for the demonstration of virus.

The results are discussed and compared with recent German and American studies.

\section{ZUSAMMENFASSUNG}

Untersuchungen mit verschiedenen Metoden zum Nachweis von hochund swachvirulenten Schweinepestvirus in Organen von experimentell infizierten Schweine.

Es wurden Infektionsversuche mit zwei deutschen Stämmen des Schweinepestvirus durchgeführt. In einem Versuch (Versuch I) wurden 10 Schweine der dänischen Landrasse mit einem hochvirulenten Stamm infiziert, während 10 Schweine in einem anderen Versuch (Versuch II) mit einem weniger virulenten Virus infiziert wurden.

Die Tiere wurden zu verschiedenen Zeitpunkten nach der Infektion getötet und Organe wurden zur Untersuchung mit fluoreszierenden Antikörpern (FA), der Komplementbindungsprobe (CFT) und der Agar-Gel-Diffusionsprobe (AGT) entnommen. Eine FA-Färbung von Chryostatschnitten von Tonsillen, Milz und Lymphknoten wurde vorgenommen. Gewebesuspensionen, aus denselben Organe hergestellt, wurden auf primäre Schweinenierenzellenkulturen überführt, die ebenfalls mit FA gefärbt wurden. Zur CFT-Probe wurde ein aus Milzgewebe hergestelltes Antigen benutzt, während zur AGT-Probe Stücke vom Pankreasgewebe benutzt wurden.

Das hochvirulente Virus liess sich leicht in allen infizierten Schweinen mit FA nachweisen, 'sowohl bei einer direkten Färbung von Cryostatschnitten wie bei einer Färbung der okulierten Gewebekulturen. CFT und AGT waren positiv wo die geprüften Organe von Tieren stammten, die in einem mehr avancierten Stadium der Krankheit getötet worden waren.

Das weniger virulente Virus konnte bei FA-Färbung der Gewebeschnitte bei 8 von den 10 Schweinen in Versuch II nachgewiesen werden. Dagegen gelang es bei keinem der Tiere mit Hilfe der FA-Gewebekulturmethode Virus nachzuweisen. CFT war positiv in einem Fall und AGT in 3 Fällen.

In beiden Versuchen zeigte die FA-Färbung der Chryostatschnitte von Tonsillen sich als eine besonders geeignete Methode zum Nachweis von Virus.

Die Ergebnisse werden diskutiert und mit neueren deutschen und amerikanischen Untersuchungen verglichen. 


\section{SAMMENDRAG}

Undersфgelse over forskellige diagnostiske metoders anvendelighed ved påvisning af høj-og lavvirulent svinepestvirus $i$ organer fra eksperimentelt inficerede svin.

Der er udf $\varnothing$ rt podningsfors $\varnothing \mathrm{g}$ med to tyske stammer af svinepestvirus. I et fors $\varnothing \mathrm{g}$ (fors $\phi \mathrm{g} \mathrm{I}$ ) blev 10 grise af dansk landrace podet med en højvirulent stamme, medens 10 grise i et andet fors $\varnothing$ g (fors $\varnothing$ g II) blev podet med lavvirulent virus.

Dyrene blev aflivet på forskellige tidspunkter efter podningen, og organer blev udtaget til unders $\varnothing$ gelse med fluorescerende antistoffer (FA), komplementbindingspr $\varnothing$ ven (CFT) og agar-gel-diffusionspr $\varnothing v e n$ (AGT). Der foretoges FA-farvning af kryostatsnit af tonsiller, milte og lymfekirtler. Vævssuspensioner fremstillet ud fra de samme organer blev podet på primære svinenyrekulturer, der ligeledes farvedes med FA. Til CFT anvendtes antigen fremstillet ud fra miltvæv, medens der til AGT anvendtes stykker af pancreasvæv.

Det højvirulente virus kunne let påvises i alle de podede grise med FA, både ved direkte farvning af kryostatsnit og ved farvning af de podede vævskulturer. CFT og AGT var positive, når de afprøvede organer stammede fra dyr, der var aflivet $i$ et mere avanceret stadium af sygdommen.

Det lavvirulente virus kunne påvises ved FA-farvning $\mathrm{i}$ vævssnit fra 8 af de 10 grise i fors $\emptyset$ g II. Det lykkedes derimod ikke at påvise virus fra nogen af dyrene ved FA-vævskulturmetoden. CFT var positiv i 1 tilfælde og AGT i 3 tilfælde.

I begge fors $\varnothing \mathrm{g}$ viste FA-farvning af kryostatsnit af tonsillerne sig som en særlig velegnet metode til påvisning af virus.

Resultaterne diskuteres og sammenholdes med nyere tyske og amerikanske unders $\emptyset$ gelser. 